\title{
Reflections on Legal Uncertainties for e-Commerce Transactions in Cameroon $^{1}$
}

\section{Caroline Joelle Nwabueze}

Post-Doctorate Research Fellow, at the South African Research Chair in Law, Society and Technology, College of Law, University of South Africa (UNISA), Pretoria

\begin{abstract}
This thematic report appraises legal provisions currently governing e-commerce transactions in Cameroon, in particular the matter of online contracts for sales of goods and services. There are uncertainties for Cameroonian consumers in the legal provisions at both regional level - via the Organisation pour l'Harmonisation en Afrique du Droit des Affaires (OHADA, the Organisation for the Harmonisation of Business Law in Africa) - and at Cameroonian national level. The report recommends steps to be taken to remedy the uncertainties.
\end{abstract}

\section{Keywords}

e-commerce, online transactions, online contracts, OHADA, consumer protection

DOI: https://doi.org/10.23962/10539/23499

\section{Recommended citation}

Nwabueze, C. J. (2017). Reflections on legal uncertainties for e-commerce transactions in Cameroon. The African Journal of Information and Communication (AJIC), 20, 171-180. https://doi.org/10.23962/10539/23499

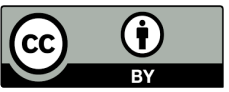

This article is licensed under a Creative Commons Attribution 4.0 International (CC BY 4.0) licence: http://creativecommons.org/licenses/by/4.0

1 This thematic report draws on the contents of the author's paper presented at the International Colloquium on Consumer Protection, University of Yaoundé II, Cameroon, in January 2017. The author's participation in the conference was supported by sponsorship from the South African Research Chair in Law, Society and Technology, University of South Africa (UNISA), by South Africa's Department of Science and Technology (DST), and by the National Research Foundation (NRF) of South Africa. 


\section{Introduction}

Increased use of computers, Internet and other information and communication technology (ICT) tools have led to tremendous changes in the practices of commerce (Bolton, 2009). ICT-enabled mechanisms have engendered a vast electronic marketplace for the conclusion of contracts for sale of goods and services. The global e-commerce system draws much of its power from the savings it enables in terms of cost, time, distance, and efficiency (Boss, 2015). Internet-enabled e-commerce is allowing for continuous changes in the way companies do business (Estrella-Faria, 2009). Accordingly, if e-commerce is to fulfill its economic empowerment potential, legal systems do need to be adjusted so as to accommodate the emerging business practices.

A core difficulty is that distance selling in the course of e-transactions in the cyberspace was never envisaged by the legislator of the traditional law of contracts (Pistorius, 2004). Purchasing goods or services on this basis does mean that it is difficult for the customer to examine them prior to concluding a contract (Lloyd, 2014). The principles of law of contracts are old, shaped for a world of ink and paper (Pistorius, 2004). Their transplantation in e-commerce contract formation raises numerous questions. Specifically, it is crucial to have clear legal entitlements for online expression of an offer, and online acceptance of an offer, in order to preserve contract enforceability.

In this report, I set out some of the issues at play for contract formation (offer and acceptance) in the new environment of electronic commerce. I then give a sense of how the African regional inter-governmental legal organisation, the Organisation pour l'Harmonisation en Afrique du Droit des Affaires (OHADA, the Organisation for the Harmonisation of Business Law in Africa), has engaged with e-commerce matters to date, followed by consideration of how one OHADA Member State, Cameroon, has engaged at national level. I then identify gaps that will need to be addressed by lawmakers at either OHADA or Cameroonian national level in order for e-commerce to achieve its full potential as a source of economic empowerment in Cameroon.

\section{Contract formation in the online sphere}

It is universally recognised that consent to an "invitation to treat" (i.e., an offer to sell) plays an unequivocal role in the formation of a contract in the field of business. This consent provides both parties with clarity and certainty as to the terms and object of the transaction, and their acquiescence in respect of the characteristics of the goods or services to be provided in terms of the transaction. Security in a commercial agreement cannot be ascertained in the absence of certainty that both parties have effectively agreed to the transfer of the goods, and to the terms of the transfer. 
A difficulty with the online realm, as legal scholar Dahiyat (2011) explains, is the absence of face-to-face encounter between buyer and seller:

[because] it is likely that online parties will have no previous or personal knowledge of their partners, it is difficult to expect them to be sure of the identity and correctness of their partners or to know whether an electronic order is in fact placed by the person who pretends to be the offeror. It may also be very difficult for them to determine precisely whether the content of an order is altered during its transmission from the sender to the recipient.

(Dahiyat, 2011, p. 298)

The rules of ethics and contractual loyalty in business agreements require that the parties to a contract must have received full knowledge of the terms of the offer before giving their agreement. Such rules can become strained in the context of online contract formation for online transactions. Face-to-face interaction in the course of formation of business agreement in the paper-based environment is susceptible to fewer mistakes than in the online environment.

Online business transactions make use of the Internet or other electronic media in the pre-contractual period of negotiation. During this period, the two parties, the seller and the buyer, have potentially conflicting interests. These contrasting interests coupled with distance and online impersonalisation have the potential to make it difficult for parties to the agreement to determine precisely whether the offer (or acceptance), as electronically expressed, clearly reflects the intent of the other party. Because of the foregoing, it is important for legislation to take into account the issues peculiar to online commercial contracts, during which, among other things, consumers are potentially exposed to fraudulent practices (Erasmus, 2011).

One example of a fraught issue is whether a click on an icon on the website of a vendor - in the case, for example, of click-through agreements (also known as "click-wrap agreements") - can qualify as unequivocal assent. In other words, is the consumer bound into an online contract by clicking on an icon provided on a trader's website? This question has been raised before numerous courts.

In the case in Davis v. HSBC Bank Nevada, N.A., the plaintiff filed a class action complaint alleging among others false advertising. The plaintiff contended that the relevant portions of the terms and conditions were not visible without scrolling down on the trader's website. The court found that the plaintiff's failure to read the terms and conditions before checking the box accepting the terms was irrelevant to determining enforceability. The court reasoned that the contested annual fee was "within the plaintiff's observation", and therefore binding. 
In another case, Jerez v. JD Closeouts, the court found that if the "terms of sale" are simply buried or "submerged" in multiple layers of web pages, and such terms are not specifically brought to the consumer's attention, their content will not be deemed part of the parties' agreement. Thus, uncertainty still exists as to whether or not a click by the consumer constitutes a legally recognisable act signifying one's intent to be contractually bound as such where terms were unilaterally imposed (Snail, 2008, p. 4).

\section{Legal provisions in OHADA}

OHADA is an inter-governmental body, established by treaty in 1993, that currently has 17 Member States, including Cameroon. With the exception of Comoros (an East African island state), all OHADA Member States are in Central and West Africa. And with the exception Equatorial Guinea (a formers Spanish colony), all OHADA members are former French colonies. ${ }^{2}$

One of OHADA's core functions is the issuance of Uniform Acts, which are directly applicable in all Member States. OHADA Uniform Acts do not, however, prevent the Member States from enacting specific legislation in the same sphere as that covered by a Uniform Act, provided the national legislation does not conflict with the Act (Martor, Pilkington, Sellers, \& Thouvenot, 2007).

On e-commerce matters, the relevant OHADA instrument is the 2010 revised OHADA Uniform Act on General Commercial Law, which became effective in Member States in 2011. At the level of the Union Economique et Monétaire Ouest Africaine (UEMOA, West African Economic and Monetary Union), Regulation No. 15/2002/CM/UEMOA on Payment Systems aims at development of business transactions among UEMOA Member States (UEMOA, 2002). However, while the Regulation does contribute to modernising the UEOMA monetary market, it is silent on online transactions.

The UN Convention on Contracts for the International Sale of Goods (CISG), adopted in 1980, is the fundamental legal instrument regulating the sale of goods at the international level (UNCITRAL, 1980). However, CISG does not refer to electronic commerce. The 1996 UN Commission on International Trade Law (UNCITRAL) Model Law on Electronic Commerce requires that UNCITRAL Member States ensure that such contracts are legally binding on the parties (UNCITRAL, 1996).

2 OHADA's Member States are Benin, Burkina Faso, Cameroon, Central African Republic, Côte d'Ivoire, Congo, Comoros, Gabon, Guinea, Guinea Bissau, Equatorial Guinea, Mali, Niger, the Democratic Republic of Congo (DRC), Senegal, Chad and Togo. 
However, as of late 2017, among the 17 OHADA Member States, only Central African Republic, Congo, and Senegal have ratified the UNCITRAL Model Law's provisions. $^{3}$

On consumer protection matters, OHADA has not produced any legal provisions, leaving development of consumer protection legislation to national OHADA Member State legislators. The Napoleonic Civil Code is the fundamental text of law used to regulate sale of goods and consumer related aspects in the OHADA countries.

The aforementioned 2010 revised OHADA Uniform Act on General Commercial Law includes significant provisions in respect of (1) validity of electronic documents and (2) validity of electronic signatures.

\section{Validity of electronic documents}

Under Chapter 2 of the revised Uniform Act, the formalities performed by the Registre du Commerce et du Credit Immobilier (RCCM, Trade and Credit Register) in respect of electronic documents and electronic transmissions, have the same legal effect as those accomplished with documents in paper form, in particular as regards their legal validity and their probative force (Art.82). Thus, the Act gives the possibility, to the parties in an online transaction, to present documents in electronic form as substitutes for paper-based documents. Documents in electronic form are recognised as equivalent when they are established and maintained by a reliable technical process which at all times guarantees the origin of the document in electronic form and its integrity during electronic processing and electronic transmission. Under the revised Uniform Act, the origin of documents in electronic form and their integrity during electronic processing and electronic transmission must be guaranteed by reliable technical processes. OHADA has, accordingly, established a Technical Committee for the Standardisation of Electronic Procedures.

\section{Validity of electronic signatures}

The revised Uniform Act recognises as valid ("qualified") an electronic signature carried via a reliable technical process that guarantees: the origin of documents in electronic form at all times; and the documents' integrity during processing and electronic transmission. Article 83 provides that a valid electronic signature applied to a document is one that makes it possible to identify the signatory and for the signatory to express consent to the obligations arising from the signature.

Further, the Act states that the electronic signature, in order to be valid, must: be linked to only the signatory; allow the signatory to be properly identified; have been

3 See http://www.uncitral.org/uncitral/en/uncitral texts/electronic commerce/1996Model status. $\underline{\mathrm{html}}$ 
created by means which the signatory can retain under her/his exclusive control; and be linked to the document to which it relates in such a way that any subsequent modification of the document is detectable. And a valid electronic signature under the Act must: be generated by a signature-creation software and signature-verification software; and include an electronic certificate, authenticating the signatory, that is produced by an electronic certification service provider. The Act does not specify whether the signature-creation software should be two different pieces of software, or two elements of a single piece of software. The Act gives authority to the Technical Committee for the Standardisation of Electronic Procedures to determine the criteria to be fulfilled in order to be an electronic certification service provider.

The Act recognises the right of the parties to the online transaction to use the dispositions of Member States' domestic law to palliate (i.e., moderate) OHADA regulations regarding the technical constraints applied to the components of the electronic signature, so that it is deemed to be qualified (Art. 84). Judgements by the French Supreme Court (Cour de Cassation) provide some African OHADA judges with inspiration when it comes to the recognition of electronic signatures. The validity of use of a secure device for creating electronic signatures has, for example, received judicial blessing in France. In a judgment of 6 April 2016, the French Cour de Cassation confirmed the ruling of the Montpellier District Court in a dispute related to the validity of an electronic signature (Cour de Cassation, 2016). The judge in the case considered that the electronic contract had been established and kept in a manner that guaranteed its integrity, because the signature had been identified by a reliable process guaranteeing the link between the electronic signature and the act to which it was attached.

While the aforementioned provisions of the OHADA Uniform Act constitute encouraging developments for OHADA Member States' consumers in e-commerce transactions, several important matters are not fully addressed in the OHADA instrument and must thus be addressed via national instruments. The Act is silent on necessary details in online business practices such as terms of offer in electronic transactions, and online transaction security. Accordingly, several e-commerce matters have been left up to the Member States' sovereign lawmaking. I now examine what has been done at the national level in Cameroon.

\section{Legal provisions in Cameroon}

Located on the Gulf of Guinea in West Africa, Cameroon has a population of approximately 20 million people. Due to its varied colonial history, during which the country experienced periods of German, British and French control, Cameroon has a dual - or bijural - legal system, with English common law operating in certain regions (primarily in the west), and French civil law operating in other regions (DocuSign, n.d.). Cameroon's legal instruments relevant to this report are its Law No. 2010/021 
of 21 December 2010 governing e-commerce and its Law No. 2011/012 of 06 May 2011 on consumer protection.

Article 10 of the 2010 e-commerce law stipulates that the law regulating the formation of traditional written contracts will apply to electronic contracts in respect of agreement, validity, and enforcement. But, as explained above, transposing traditional notions of commercial law to a purely electronic environment raises certain fundamental issues with respect to formation of contract. Two such issues are: (1) presumption of reception of documents related to an online transaction; and (2) presumption of conclusion of a contract for an online transaction.

\section{Presumption of reception of documents related to an online transaction}

In the eyes of the law, at what particular period of time a message sent by a party in the course of an online transaction, is supposed to have taken legal effect? Such understanding is primordial to the successful conclusion of the online agreement by both parties.

Article 12(3) of Cameroon's Law on e-commerce underlines that: "The order, the confirmation of acceptance of the offer and the acknowledgement of receipt are presumed to have been received when the receiving party was able to access the documents". The law does not clarify what is meant by "able to access the documents" in an online environment. Does this refer to the consumer ability to read, or to open, or to click on, or to merely notice the mentioned document on the trader's website? This lack of clarity, which generates uncertainty in the practice of online trade, must be the subject of legal amendments.

\section{Presumption of conclusion of a contract for an online transaction}

Article 12 of Cameroon's Law on e-commerce (Law No. 2010/021 of 21 December 2010) stipulates that:

- A contract cannot be concluded unless the offeree was given the opportunity to access and review the details of the offer prior confirming his acceptance. (Art. 12(1))

- Within 5 days, the offeror must acknowledge receipt of the online order sent to him. (Art. 12(2))

However, the above-mentioned conditions of Article 12 do not apply to contracts exclusively concluded through emails, individual communications, or transactions between persons knowledgeable in the field. This implies that offer and acceptance sent through emails do not need further time for review or acknowledge receipt. The email stands as offer or acceptance, with the exception of contracts concluded between professionals (Art. 12(4), Law No. 2010/021 of 21 December 2010). It is 
my view that this presumption of conclusion of an electronic contract in an online environment constitutes an abuse of consumers' rights. In the particular context of the computer illiteracy of a large number of Cameroonians, opportunities should be given to online consumers to access and review the terms of the offer, prior to being bound as a matter of law. Enforceability should vary according to the methods of offer or acceptance used (Van Der Merwe et al., 2016).

Given the uncertainties in Cameroon's e-commerce law in respect of online contract formation, it becomes relevant to consider whether Cameroon's 2011 consumer protection law is of assistance.

\section{The consumer protection law}

Article 3(c) of Cameroon's consumer protection law (Law No. 2011/012 of 06 May 2011) establishes:

The principle of information according to which consumers have the access to information to enable them to make an informed choice during any transaction concerning the supply of technology, goods, and services. (Art. 3(c), Law No. 2011/012 of 06 May 2011)

Chapter 3 of the above-mentioned law protects the consumer's economic and technological interests. More specifically, Article 5(2) declares that: "[a] competent court may declare contractual clauses void", when such clauses:

- Exempt, exclude, reduce or limit the liability of suppliers or service providers for defects, deficiencies or shortages of any kind in technology, the good supplied or service rendered;

- Imply the loss of rights and freedoms guaranteed to consumers, or limit the exercise thereof;

- Create unjust, unreasonable, unfair or repressive contractual terms or conditions, or that transfer liability for defects, deficiencies or shortages not immediately obvious to the consumer;

- Impose a unilateral arbitration clause. (Art. 5(1), Law No. 2011/012 of 06 May 2011)

Because the national legislator in Cameroon did not define the standards of "informed choice", it could be difficult to argue that a trader by placing an icon on the website of the online shop linking to the terms and conditions, is liable for practising misinformation for assuming the contract concluded once the consumer has clicked on the icon. It is the author's view that common law principles designed for a "bricks and mortar" world could be adapted in order to be effective in a digital environment. An online provided offer/acceptance should reflect in this sense the essential characteristics of precision and clarity. It should represent a proposal sufficient in terms of legal contracting to enable an informed acceptance by the consumer. 


\section{Recommendations}

\section{A new OHADA instrument}

One possible solution to the legal uncertainties outlined above is for OHADA Member States to collaborate in development of an OHADA regional instrument on consumer protection. Such an instrument could alleviate the current uncertainties in the legal provisions of Cameroon (and other OHADA Member States) in respect of online contracts. Moreover, such an instrument could, in addition to legislating on e-commerce matters, legislate on other important consumer matters such as: consumer participation in financial markets, consumer over-indebtedness, consumer contact with defective goods, unfair competition, and access to redress. This OHADA instrument could either take the form of a Uniform Act binding on all OHADA Member States, or a Model Law serving as a standard for Member States.

\section{Strengthened Cameroonian provisions}

Another option is for Cameroon to take steps at its sovereign national level to strengthen the protection of consumers in online business transactions. Such steps could be taken via a detailed law specific to online transactions, or via upgrades to the existing e-commerce and consumer protection laws to fill the gap of uncertainty in the digital business environment.

\section{References}

Bolton, D. (2009). Shrink-wrap and click-wrap contracts. Precedent, 95. Retrieved from http://www.austlii.edu.au/au/journals/PrecedentAULA/2009/97.pdf

Boss, A. E. (2015). Practicing e-legally. The United Nations Convention on the Use of Electronic Communications in International Commerce. In S. Linton, G. Simpson, \& W. A. Schabas (Eds.), For the sake of present and future generations: Essays on international law, crime and justice in honour of Roger S. Clark (pp. 555-573). Leiden, Netherlands: Brill. https://doi.org/10.1163/9789004270725 035

Cour de Cassation. (2016). Cour de Cassation, Chambre Civile 1. Audience publique du mercredi 6 avril 2016. No. de pourvoi: 15-14631.

Dahiyat, E. A. R. (2011). The legal recognition of electronic signatures in Jordan: Some remarks on the Electronic Transactions Law. Arab Law Quarterly, 25(3), 297-309. https://doi.org/10.1163/157302511x568538

Davis v. HSBC Bank Nevada, N.A., 691 F.3d 1152, 1162 (9th Cir. 2012).

DocuSign. (n.d.). eSignature legality in Cameroon. Retrieved from https://www.docusign. com/how-it-works/legality/global/cameroon

Erasmus, C. (2011). Consumer protection in international electronic contracts. Master of Laws dissertation, Northwest University, Potchefstroom, South Africa. Retrieved from http://dspace.nwu.ac.za/bitstream/handle/10394/6917/Erasmus_C. pdf? sequence $=2$

Estrella-Faria, J.-A. (2009). Legal aspects of electronic commerce: Rules of evidence, contract formation and online performance. In Xiamen Academy of International Law (Ed.), Collected courses of the Xiamen Academy of International Law, vol. 2. Leiden, Netherlands: Brill. https://doi.org/10.1163/ej.9789004180932.i-474.21 
Jerez v. JD Closeouts, LLC, 943 N.Y.S.2d 392, 394 (Dist. Ct. 2012).

LawTeacher. (n.d.). Electronic contracts. Retrieved from https://www.lawteacher.net/freelaw-essays/contract-law/electronic-contracts.php

Lloyd, I. J. (2014). Information technology law (7th ed.) New York: Oxford University Press.

Martor,B.,Pilkington, N., Sellers, D. S., \&Thouvenot, S. (2007). Business law in Africa: OHADA and the harmonisation process (2nd ed.). Retrieved from https://www.bookdepository. com/OHADA-Harmonization-Process-Boris-Martor/9781846730726

Organisation pour l'Harmonisation en Afrique du Droit des Affaires (OHADA). (2010). Uniform Act on General Commercial Law [revised]. OHADA Official Gazette Special Issue of 15 February 2011.

Pistorius, T. (2004). Click-wrap and web-wrap agreements. South African Mercantile Law Journal, 16(4), 568-576. http://hdl.handle.net/10520/EJC54132

Republic of Cameroon. (2010). Law No. 2010/021 of 21 December 2010 governing e-commerce.

Republic of Cameroon. (2011). Law No. 2011/012 of 06 May 2011 on consumer protection.

Snail, S. (2008). Electronic contracts in South Africa - a comparative analysis. Journal of Information, Law and Technology, 2. Retrieved from https://warwick.ac.uk/fac/soc/ law/elj/jilt/2008 2/snail

UN Commission on International Trade Law (UNCITRAL). (1980). United Nations Convention on Contracts for the International Sale of Goods (CISG). Vienna. Retrieved from https://www.uncitral.org/pdf/english/texts/sales/cisg/V1056997CISG-e-book.pdf

UNCITRAL. (1996). UNCITRAL Model Law on Electronic Commerce. Vienna. Retrieved from http://www.uncitral.org/uncitral/en/uncitral texts/electronic commerce/1996Model.html

Union Economique et Monétaire Ouest Africaine (UEMOA). (2002). Regulation No. 15/2002/CM/UEMOA relatif aux systemes de paiement dans les etats membres de l'union economique et monetaire ouest africaine (UEMOA). Retrieved from http:// www.bu.edu/bucflp-fig/files/2012/01/Regulation-No.152002CMUEMOA-onPayment-Systems-in-the-Member-States-of-WAEMU.pdf

Van Der Merwe, D., Roos, A., Nel, W., Eiselen, S., \& Nel, S. (2016). Information and communications technology law. Durban: LexisNexis South Africa. 